\title{
Application of waterflooding technique to the Angut oilfield in the northern part of Afghanistan
}

\author{
Khwaja Naweed Seddiqi ${ }^{1} \cdot$ Zabihullah Mahdi $^{1}$
}

Received: 6 December 2016/ Accepted: 23 September 2017/Published online: 3 October 2017

(C) The Author(s) 2017. This article is an open access publication

\begin{abstract}
The purpose of the paper is to use the BuckleyLeverett frontal displacement theory to evaluate the recovery of oil by waterflooding for the Angut oilfield in northern Afghanistan. The waterflooding technique, in which oil is displaced by injecting water into the underlying petroleum reservoir, is investigated for the reservoir field where oil extraction has not been started. The effectiveness of the waterflooding technique is demonstrated by laboratory experiments using a horizontal plane model. The relative permeabilities of oil and water, residual oil saturation and irreducible water saturation are inspected through the experiments. The theory is then applied to the Angut oilfield to evaluate the amount of oil recovery from Angut oilfield by waterflooding technique.
\end{abstract}

Keywords Buckley-Leverett · Waterflooding $\cdot$ Petroleum reservoir engineering $\cdot$ Two-phase flow $\cdot$ Immiscible displacement in porous media $\cdot$ Relative permeability

\section{Introduction}

Several decades of strife in Afghanistan have caused shortages of the energy required to improve living conditions. Food, clothing, shelter, heat, sanitation, and industry, in general, depend on the availability of energy. The presence of petroleum resources has long been known in Afghanistan, but these resources have been exploited to only a limited extent.

Khwaja Naweed Seddiqi

Naweed.cedeqe@gmail.com

Zabihullah Mahdi

Zabih.mahdi@gmail.com

1 Tokai University, 4-1-1 Kitakaname, Hiratsuka 259-1292, Kanagawa, Japan
Improving living and economic conditions in Afghanistan requires increasing the availability of energy, particularly by exploitation of Afghanistan's petroleum resources. The main aim of this paper is to estimate the amount of oil produced by waterflooding technique in the Angut oilfield. The waterflooding technique has been widely used in petroleum reservoirs where the pressure is insufficient to push oil to the surface, and then inject water into the underlying stratum. The Buckley-Leverett theory is applied to the Angut reservoir which is now under exploration by the joint Afghanistan and Chinese "China National Petroleum International Watan Ltd.” (CNPCIW) group (Petzet 2016; Carstens 2009).

\section{Angut oilfield}

Angut oilfield in Kashkari block, the area of $1723 \mathrm{~km}^{2}$, is located in Sallyburee District, Jowzjan Province, in the northern Afghanistan. Kashkari oilfield is $12 \mathrm{~km}$ from SarE-Pol City in the southeast, $10 \mathrm{~km}$ from Kashkari, $5 \mathrm{~km}$ from the "Aq Darya oilfield" in the southwest and $27 \mathrm{~km}$ from the "Bazar kami oilfield" in the southeast. Angut oilfield is situated at the front of an oil-bearing belt in the eastern margin of Amu Darya Basin in Central Asia, and the northern area of the block is a major natural gas production area in Afghanistan. Figure 1 shows the geographical view of the Angut oilfield and Kashkari block (Ministry of Mines and Petroleum of Afghanistan 2013).

The field was discovered in 1959 and has been producing since that time (Gustavson Associates report 2005). Development of the field appears to have been somewhat sporadic with six additional wells drilled over an unreported period of time. The first seven wells in the field produced oil from multiple Lower Cretaceous Albian-age (Zone XI) sandstone reservoirs. In 1967, an eighth well was drilled in the field, resulting in the discovery of the deeper Hauterivian (Zone 


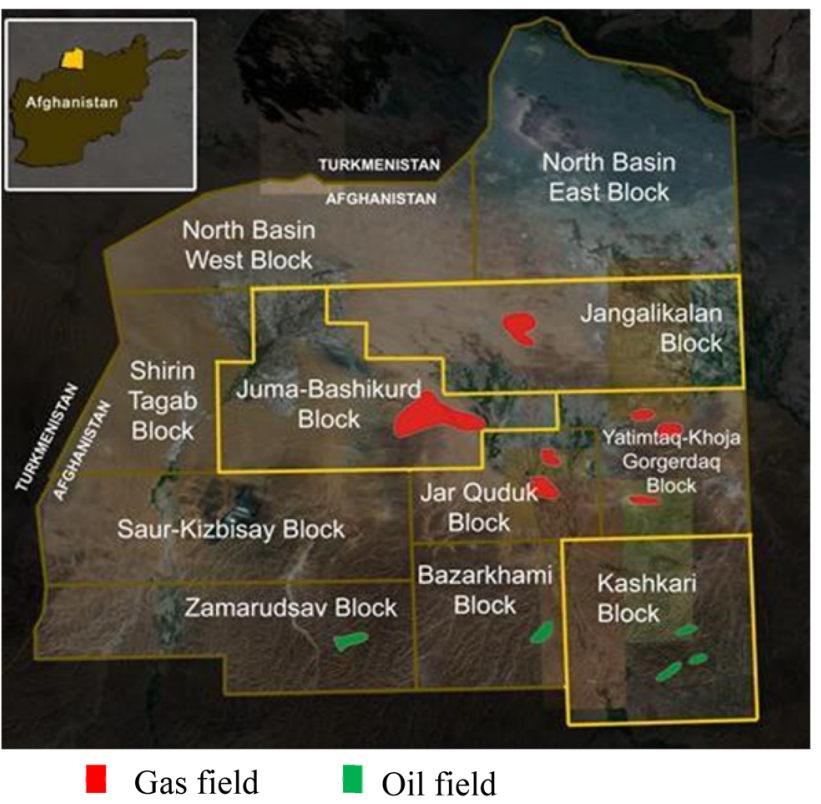

Fig. 1 Angut oilfield in Kashkari block of Amu Darya basin in the northern part of Afghanistan (Kingston 1990)

XIV) oil pool, thus renewing interest and broadening the prospects for the field (Ministry of Mines and Petroleum of Afghanistan 2013).

Since the oilfield was under local and unprofessional exploitation for a long period of war time (1980-2008), there is no exact production history for this oilfield.

\section{Geology and reservoir characteristics}

The Angut oilfield is located in a mountainous area of undulating landforms. Being in a mountainous region, the oilfield has significant topographic irregularities. In addition, great variations are found in the exposure strata. These strata are mainly Guri Formation and locally small-scale Quaternary. According to data of drilled wells, the drilled stratum is largely Cretaceous, and, from top to bottom, Guri, Turonian stage, Cenomanian stage, Albian stage, Aptian stage, Barremian stage, Hauterivian stage, and Valanginian stage were drilled, showing a normal stratigraphic sequence. The Hauterivian (XIV) stage is the main target and has a lithology that is mainly red-brownish and maroon medium-small sandstone, interbedded with siltstone and clay. The lower part is silicaclay cemented conglomerate. Figure 2 shows the geologic column of Angut oilfield for the lithology of each stratum (Ministry of Mines and Petroleum of Afghanistan 2013).

The strata are relatively explicit, and the thickness of each stratum is relatively stable. The Angut oilfield is an asymmetrical anticline structure reservoir with edge water, and the major oil layer is in group XIV of the Hauterivian stage at a depth of 1100-1200 m. The lithology is loose sandstone, and the oil layer is characterized by a thin

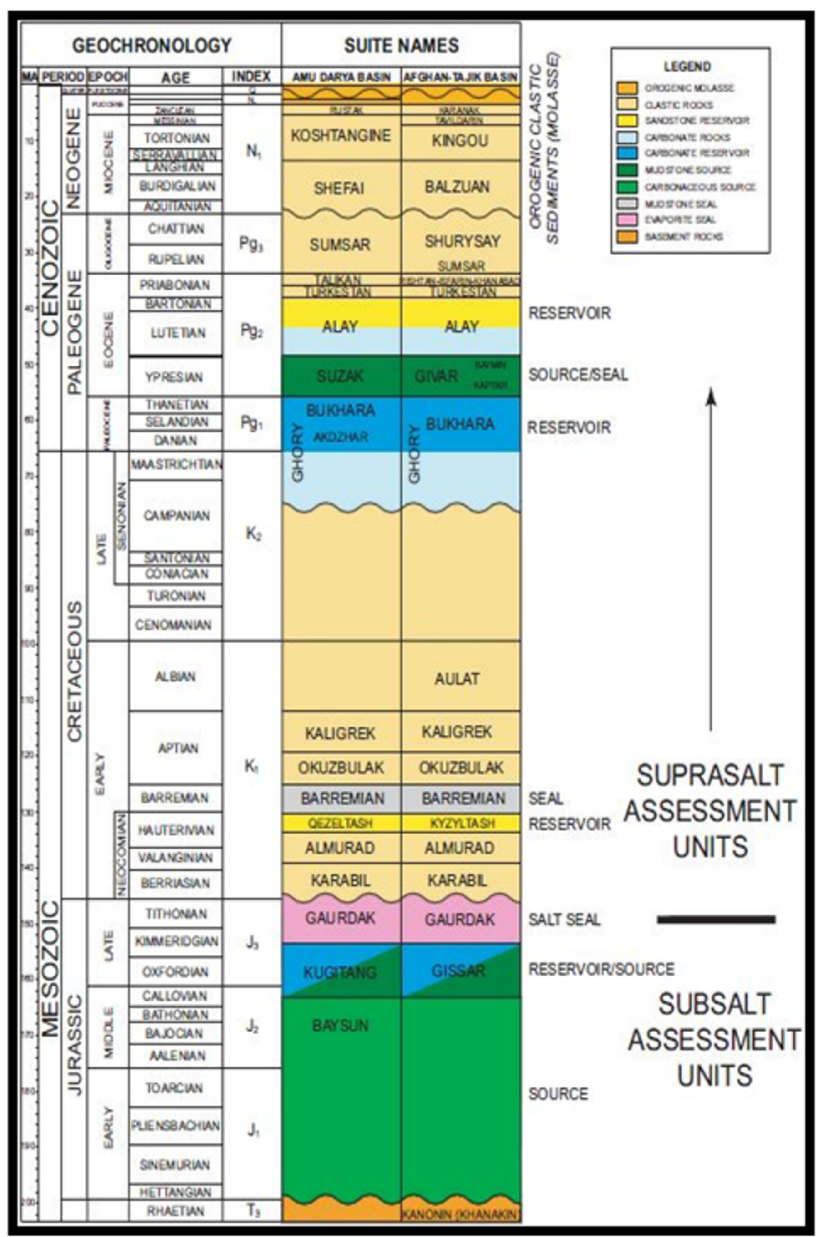

Fig. 2 Geologic column of Angut oilfield

interbed. The average thickness of group XIV is $176 \mathrm{~m}$, the effective thickness is $20 \mathrm{~m}$, and the average porosity and permeability are $17.6 \%$ and $144.2 \mathrm{mD}$, respectively.

In the Hauterivian stage, the main lithology is sandstone, consisting of $85-90 \%$ fragments and $10-15 \%$ cement material. The fragments are mainly quartz $(65-75 \%)$ and silica rock (10-15\%), including feldspar (8-10\%) and mica (5-7\%). The cement materials are mainly dolomite or calcspar, including small quantities of anhydrite and kaolinite. In the siltstone, the fragment content ranges from 60 to $90 \%$, mainly quartz (55-70\%) and dolomitic cement. The clay is composed of fine squamous clay-mica bearing material (Ministry of Mines and Petroleum of Afghanistan 2013).

The Angut oilfield is a NE-SW asymmetric anticline, with a length of $3.3 \mathrm{~km}$, a width of $1.8 \mathrm{~km}$, a structural area of $2.73 \mathrm{~km}^{2}$, and a closure of $95 \mathrm{~m}$. The southeast limb is steep, while the northwest limb is gentle. In the east, a fault with a throw of $135 \mathrm{~m}$ and an angle of $16^{\circ}-18^{\circ}$ in the NWSE direction divides the field into east and west blocks, and the west block is the main production area. No seismic exploration has been conducted in the past. Figure 3 shows UGC maps of Angut oilfield compiled from drilling data. 
The accuracy of structural features is not high in regions with fewer wells. A reserves report from 1980 repeatedly emphasized that faults have developed (both An- 6 and An14 encountered faults) in this field, and a three-dimensional seismic survey may be useful for studying the structural features and fracture zone characteristics.

\section{Laboratory experiments}

Figure 4 shows the relative permeability curves of oil and water as measured by laboratory experiments using the steady state method. In Fig. 4, as the relative permeability curve of water $k_{\mathrm{rw}}$ increases, the relative permeability curve of oil $k_{\text {ro }}$ gradually decreases. The left side of Fig. 4 shows irreducible water saturation $\left(S_{\mathrm{wr}}=0.12\right)$ and the right side shows residual oil saturation $\left(S_{\text {or }}=0.27\right)$.

The relative permeability curves with different residual oil and water saturations will be used for the design of waterflooding techniques to evaluate the amount of oil recovery by artificially injecting water into the reservoir. The rate of advancement of the water front can be calculated by Buckley-Leverett frontal displacement theory using fractional flow curves that are evaluated from the relative permeability curves (Nazari et al. 2015).

Figure 5 shows the apparatus used in oil displacement by water experiments. Fine sand (particle diameter
$D=0.105-0.425 \mathrm{~mm} ; \quad$ density of soil particles $\rho_{s}=2.65 \mathrm{~g} / \mathrm{cm}^{3}$ ), which has similar physical properties to sandstone core sample, was packed in a horizontal square plane with constant density and then saturated by oil.

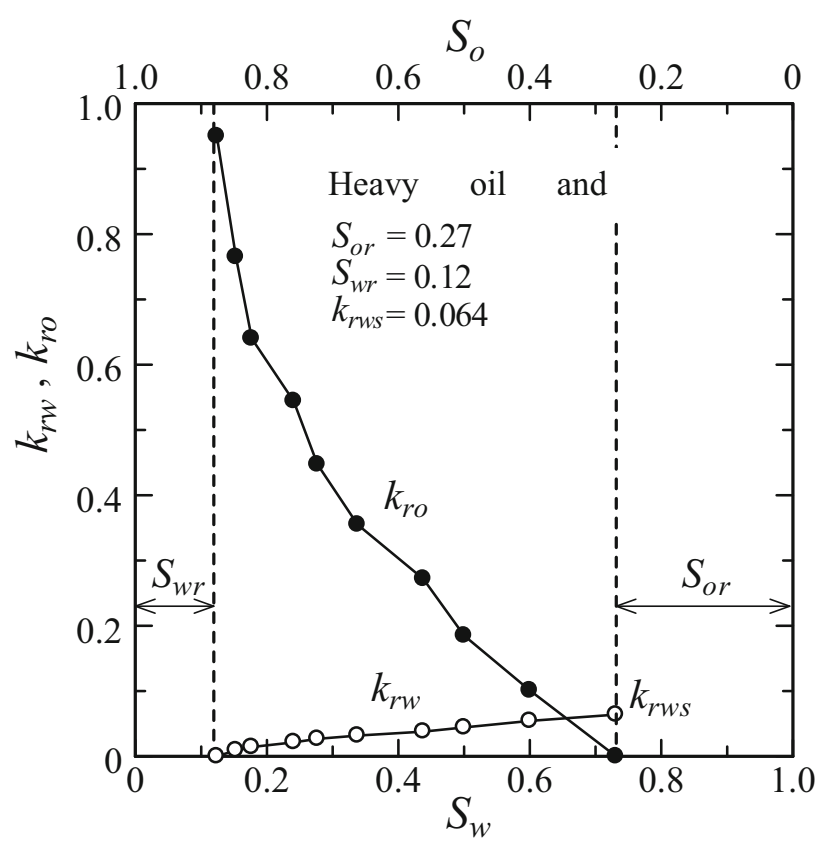

Fig. 4 Relative permeability curves for oil displacement by water (Seddiqi et al. 2016)
Fig. 3 UGC map of Hauterivian of Angut oilfield

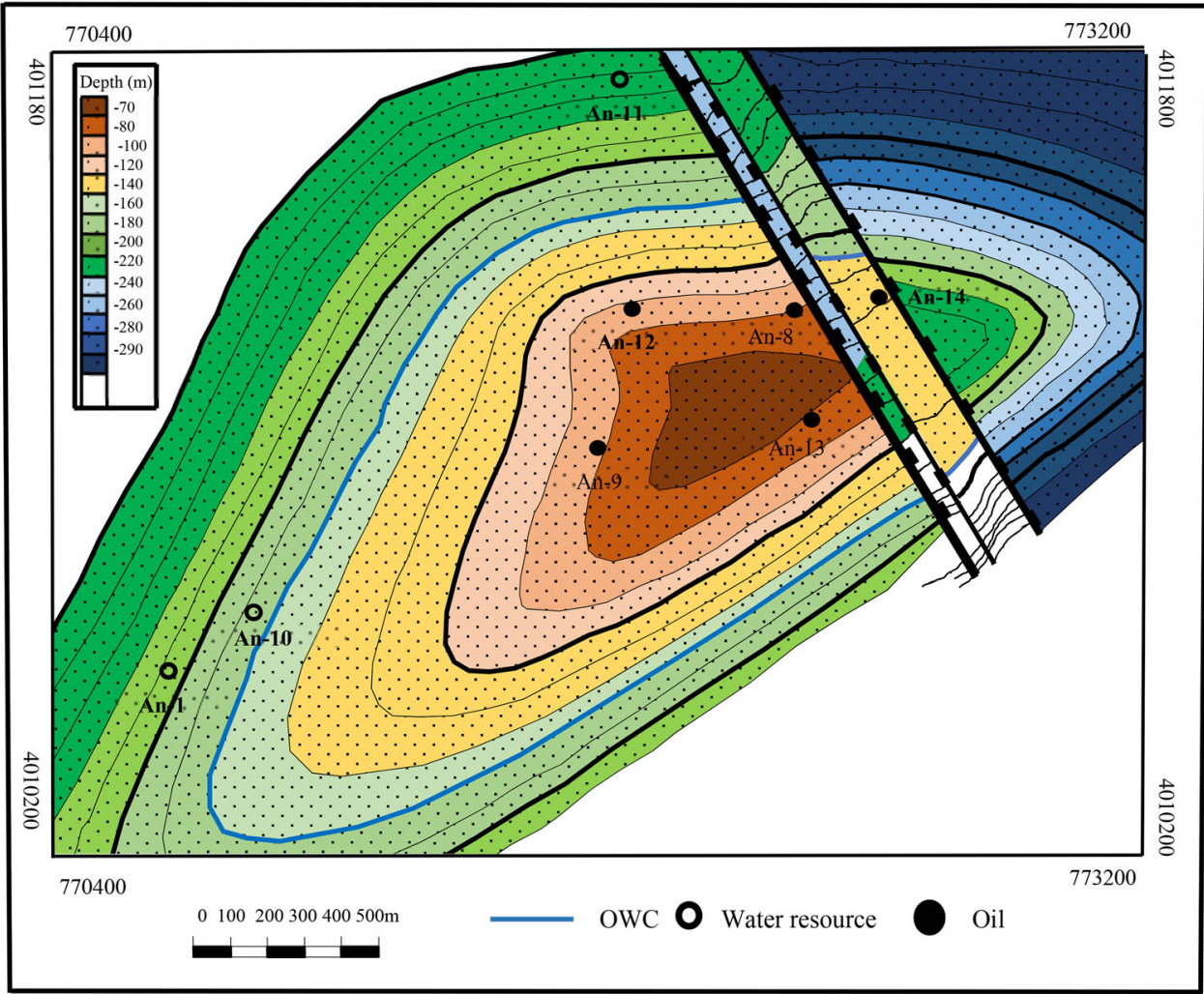




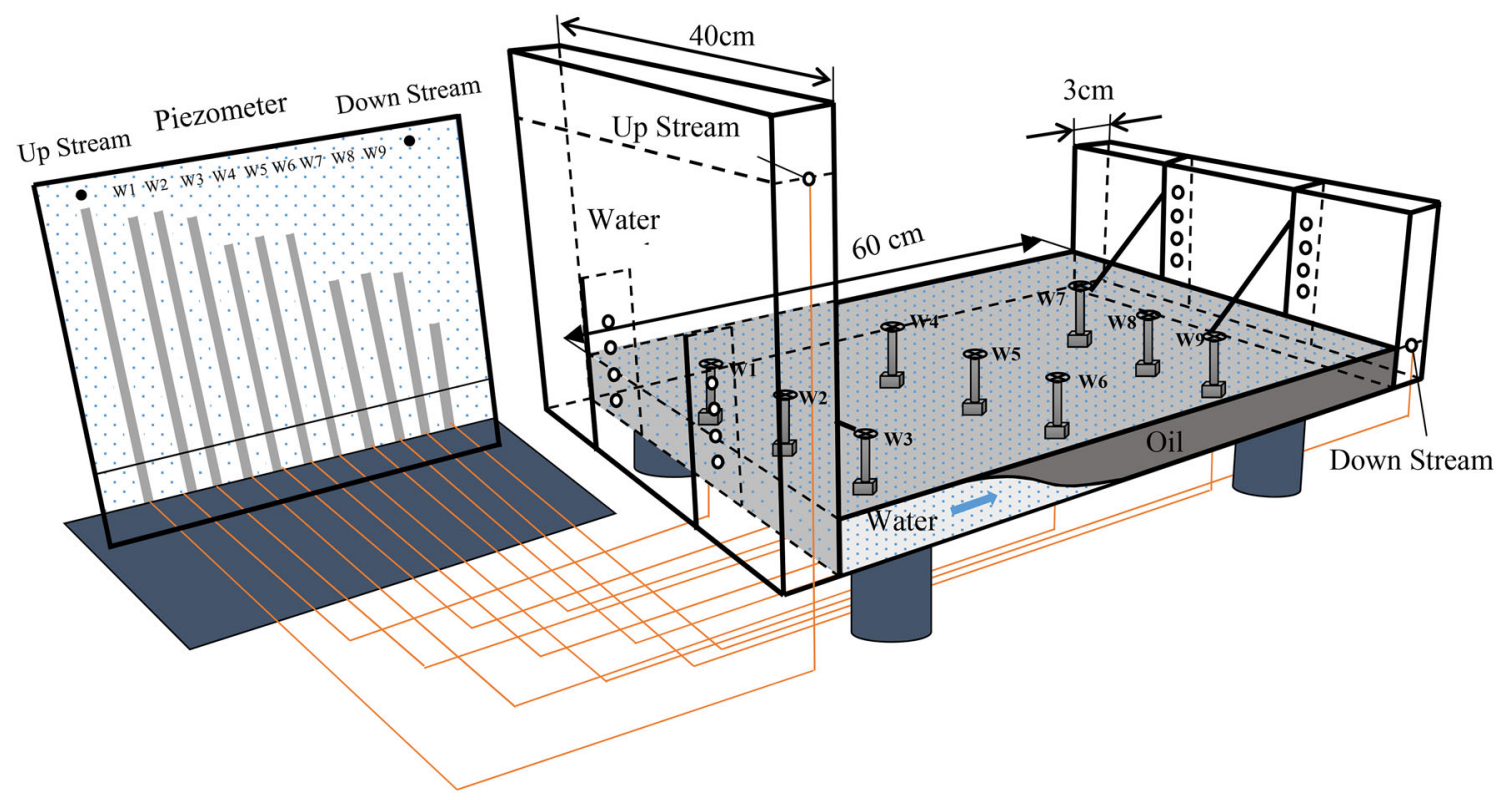

Fig. 5 Experimental apparatus

This apparatus was a regular plane and horizontal square model of length $60 \mathrm{~cm}$ and cross-sectional area $120 \mathrm{~cm}^{2}$ with $40 \mathrm{~cm}$ width and $30 \mathrm{~cm}$ thickness. A water supply tank was set up on the left side of the model. The model is made of transparent acrylic material and has 9 observation wells to measure hydraulic head during displacement. The supplied water displaces oil from the left side toward the right side, and the displaced fractional fluid discharge is collected at the end of the right side of the model.

Figure 6 shows the fractional flow discharge of oil and water obtained through the experiment $\left(q_{\mathrm{o}}=q_{\mathrm{T}}\right.$, where $q_{\mathrm{T}}$ is the total input rate). Since soil pores are initially saturated by oil, the fractional discharge of oil at the outlet $f_{\text {od }}$ is 1 until some pore volume, and later some amount of water is discharged. After $120 \mathrm{~min}$, the oil fractional discharge decreased and the water discharge increased, and after $180 \mathrm{~min}$, oil discharge from the reservoir ceased $\left(f_{\mathrm{wd}}=1\right)$. There still exists some oil in the reservoir, which indicates residual oil saturation $\left(S_{\text {or }}=0.27\right)$. In this experiment, the total amount of oil displaced by water up to $120 \min$ was $1073 \mathrm{~cm}^{3}\left(Q_{\mathrm{o}}=39 \%\right)$ from the total pore volume $\left(V_{\mathrm{v}}=V \times n=2767 \mathrm{~cm}^{3}\right)$. This experiment was performed in $180 \mathrm{~min}$, and the total discharge of fluids was $Q_{\mathrm{T}}=1610 \mathrm{~cm}^{3}$.

\section{Application of waterflooding to experimental model}

The Buckley and Leverett frontal displacement theory described a method for calculating saturation profiles when water displaces reservoir oil (Buckley and Leverett 1942).
According to this theory, the rate of advance of a plane of fixed water saturation $S_{\mathrm{w}}$ is given by

$\frac{\partial x}{\partial t}=\frac{q_{\mathrm{T}}}{A \phi}\left(\frac{\mathrm{d} f_{\mathrm{w}}}{\mathrm{d} S_{\mathrm{w}}}\right)$

where $q_{\mathrm{T}}$ is the total amount of water flow, $A$ is the crosssectional area, $\phi$ is the porosity of reservoir, and $f_{\mathrm{w}}$ is the fractional flow rate of water given by

$f_{\mathrm{w}}=\frac{1}{1+\frac{k_{\mathrm{r}}}{k_{\mathrm{rw}}} \frac{\mu_{\mathrm{w}}}{\mu_{\mathrm{o}}}}$

if capillary pressure between two fluids was neglected. $\mu_{\mathrm{o}}$ and $\mu_{\mathrm{w}}$ are the dynamic viscosities of oil and water, respectively. Figure 7 illustrates the relative permeability of oil and water curves given by the following cubic functions with respect to effective water saturation for convenience (Arabzai and Honma 2013).

$k_{\mathrm{rw}}=k_{\mathrm{rws}} S_{\mathrm{e}}^{3}$,

$k_{\mathrm{ro}}=\left(1-S_{\mathrm{e}}\right)^{3}$

where $S_{\mathrm{e}}$ is the effective (normalized) saturation, given by

$S_{\mathrm{e}}=\frac{S_{\mathrm{w}}-S_{\mathrm{wi}}}{1-S_{\mathrm{wi}}-S_{\mathrm{or}}}$

It is found from Fig. 7 that the degree of water saturation at the front $S_{\mathrm{BL}}$ is 0.51 and the average saturation behind the front is $S_{\mathrm{w}}=0.56$; Fig. 8 illustrates the advance of water front for the horizontal square plane model (Fig. 5), calculated by the Buckley-Leverett equation (Eq. 1). 
Fig. 6 Experimental results of fractional discharge of pore oil and water

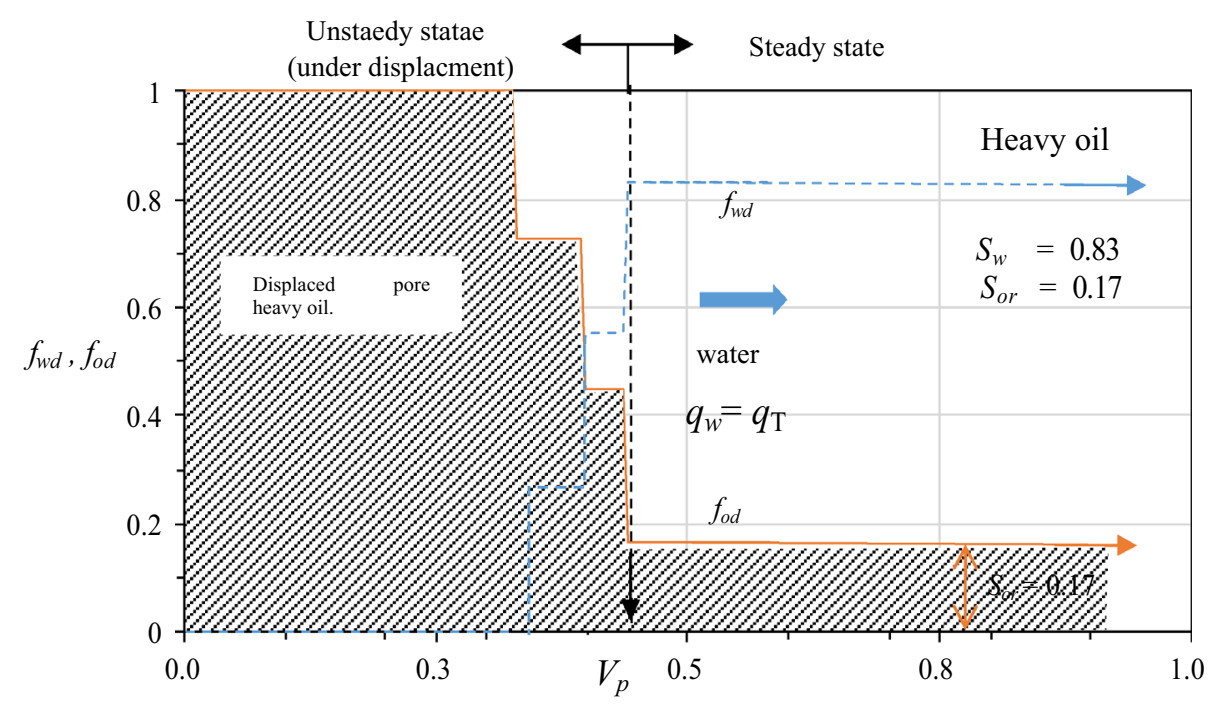

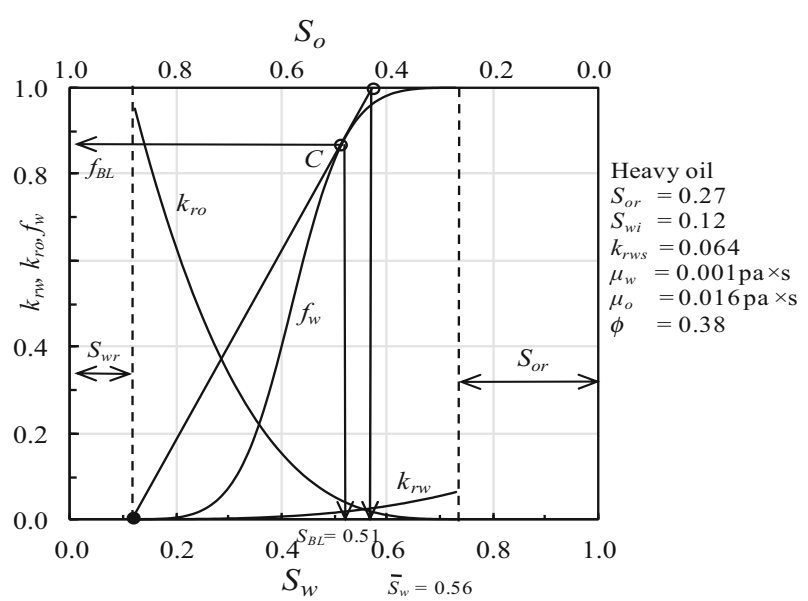

Fig. 7 Relative permeability curves of oil and water and fractional flow curve
The total amount of water injected is $q_{\mathrm{T}}=q_{\mathrm{w}}=9 \mathrm{~cm}^{3} /$ min and breakthrough occurs at $t=147 \mathrm{~min}$. The oil recovery factor at this time can be calculated as

$\mathrm{RF}=\frac{S_{\mathrm{w}}^{-}-S_{\mathrm{or}}}{1-S_{\mathrm{or}}}$

And is found to be $\mathrm{RF}=0.41$. From which the amount of oil produced up to the breakthrough is $A \phi B \times \mathrm{RF}=1252 \mathrm{~cm}^{3}$ from total pore volume $A \phi B=2746 \mathrm{~cm}^{3}$, these values nearly coincide with the experimental results.

\section{Application of waterflooding to Angut reservoir}

The asymmetric anticline Angut reservoir shown in Fig. 3 is assumed to be a rectangular reservoir with a cross-sectional area of $A=20,000 \mathrm{~m}^{2}$ and length of $x=1750 \mathrm{~m}$. Figures 9

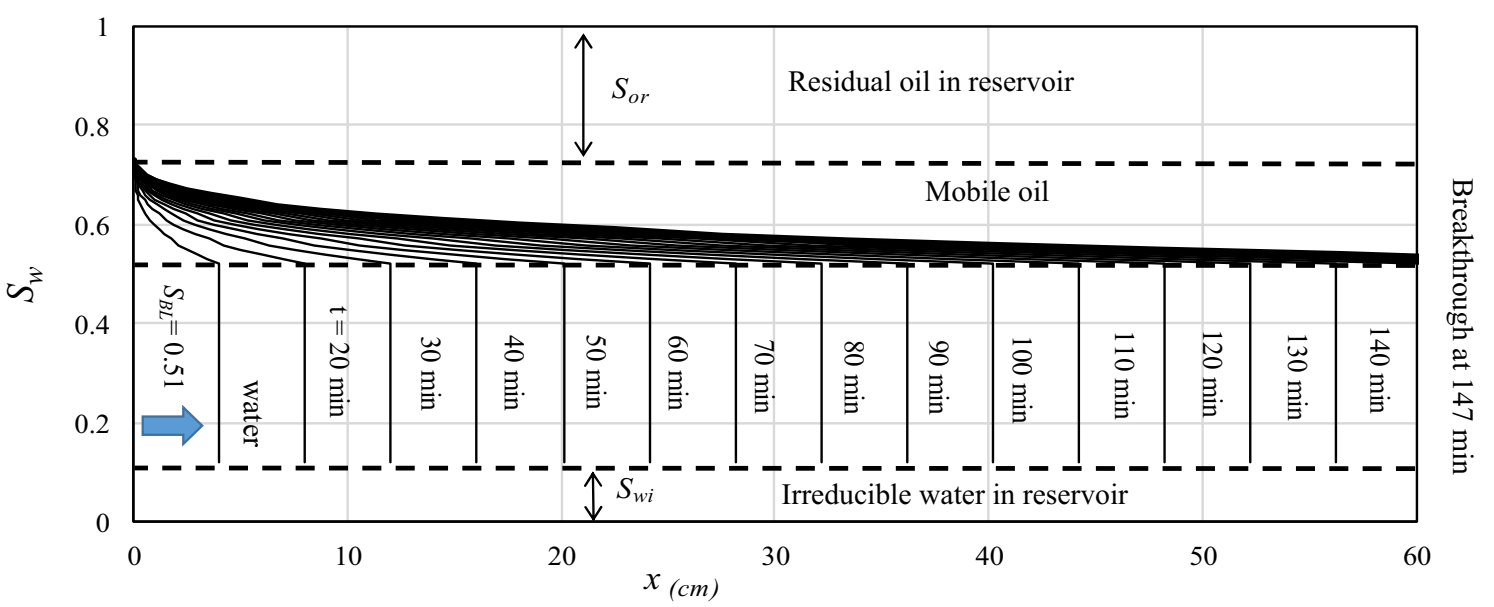

Fig. 8 Saturation profile calculated by Buckley-Leverett analysis for laboratory experiment 
Fig. 9 Top view of Angut oilfield for waterflooding operation
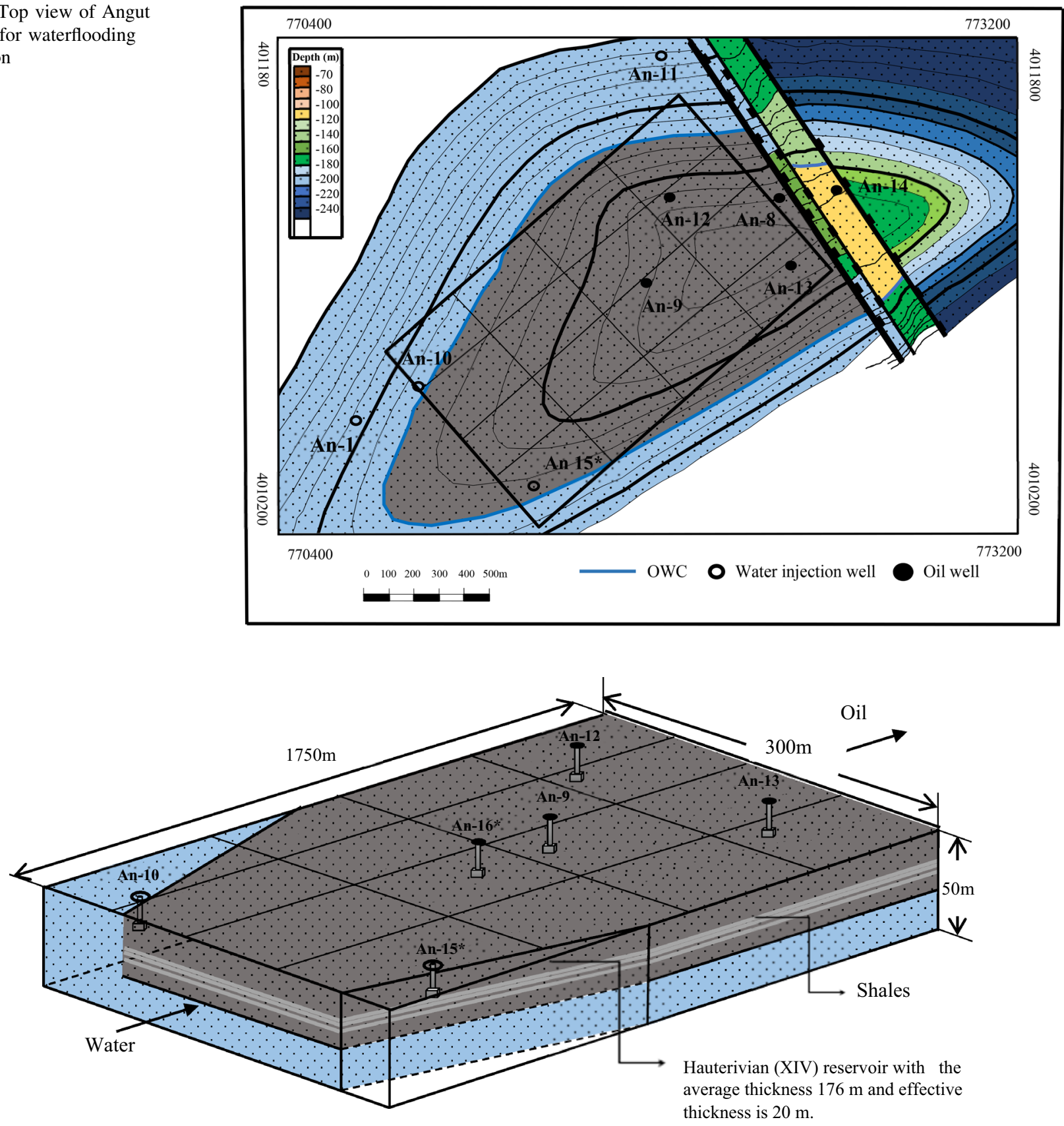

Production well $(0$ Water injection well

Fig. 10 Rectangular reservoir for waterflooding operation

and 10 show the Angut oilfield approximated as a rectangular reservoir. Three wells (An-1, An-10 and An-15) near the oil water contact in the southwest part of reservoir are assumed to be water injection wells. Because no reliable data about hydromechanical properties of this reservoir are available, the same relative permeability curves, residual oil saturation and irreducible water saturation used in the laboratory experiments are employed. The porosity of the reservoir is assumed to be $\phi=0.19$, and the rate of water injection is $1000 \mathrm{~m}^{3} /$ day.

Figure 11 shows the oil displacement by water calculated by Buckley-Leverett frontal displacement theory. It is seen from the figure that the saturation front progresses toward the exploitation wells with constant speed and 


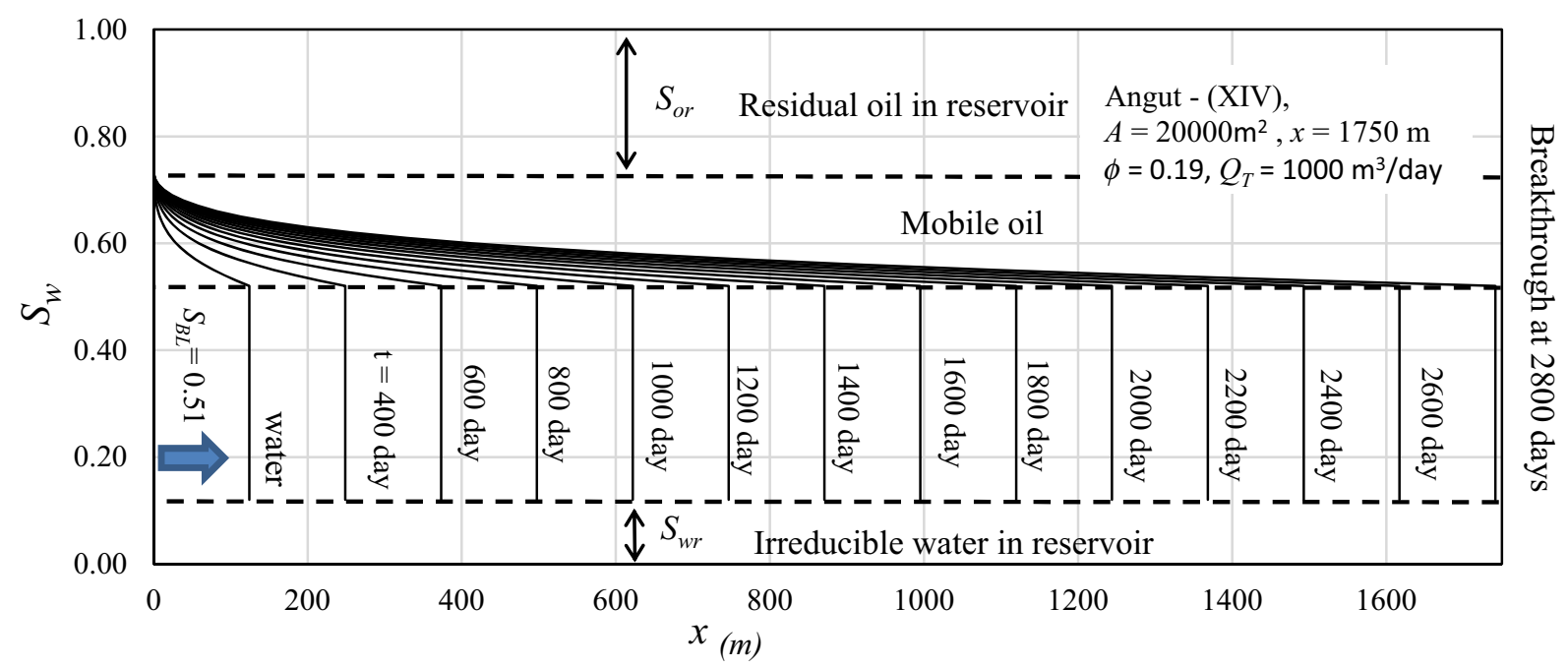

Fig. 11 Calculated results of saturation profile by Buckley-Leverett analysis for oil displacement by water

Table 1 Reserve estimation of Angut oilfield by some companies

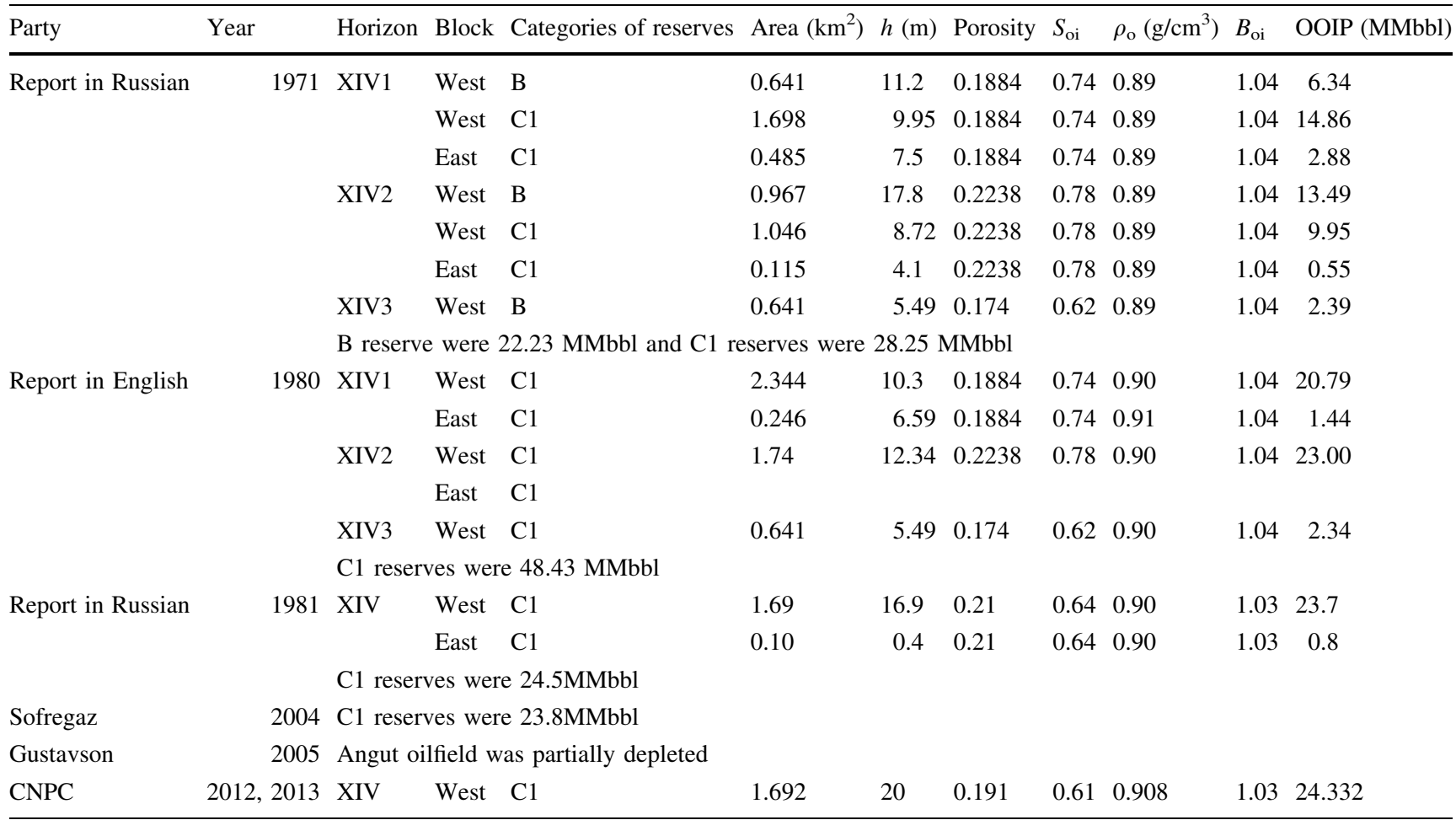

breakthrough occurs at $t=2800$ days. When breakthrough occurred, there is still some amount of mobile oil remaining in the reservoir, which may be discharged together with the water. The oil recovery factor for this reservoir is calculated from Eq. (6) and found to be $\mathrm{RF}=0.40$; consequently, the amount of oil produced up to breakthrough may be calculated as $A \phi B \times \mathrm{RF}=16.6$ MMbbl. In contrast, various different organizations evaluated the reserves of the Angut oilfield to be between 23.8 MMbbl (2005, Sofregaz) and 24.3 MMbbl (2012, CNPC). As shown in Table 1, the estimations may be based on the pore volume of the target reservoir. It is necessary to evaluate aculeate amount of reserves in due consideration of residual oil saturation and irreducible water saturation for this reservoir under waterflooding operation. 


\section{Conclusion}

The oil displacement by water in petroleum reservoir was demonstrated aiming at the Angut oilfield in northern Afghanistan. The geological and geophysical properties of this reservoir were reviled so far as indisputable. The relative permeabilities of oil and water, residual oil saturation and irreducible water saturation were evaluated in the laboratory using similar pore fluids and porous materials to the field reservoir. Subsequently, the waterflooding operation was attempted using an experimental plane model and the displacement mechanism was analyzed based on the BuckleyLeverett theory. Finally, the amount of oil recovery from Angut oilfield by waterflooding technique was estimated. It is required to measure the accurate hydromechanical properties of the reservoir with core samples, and the observational and correcting approach should be introduced in the waterflooding operation for field reservoir.

Open Access This article is distributed under the terms of the Creative Commons Attribution 4.0 International License (http:// creativecommons.org/licenses/by/4.0/), which permits unrestricted use, distribution, and reproduction in any medium, provided you give appropriate credit to the original author(s) and the source, provide a link to the Creative Commons license, and indicate if changes were made.

\section{References}

Arabzai A, Honma S (2013) Numerical simulation of the BuckleyLeverett problem. In: Proceedings of School of Engineering of Tokai University, vol 38, pp 9-14
Buckley SE, Leverett MC (1942) Mechanism of fluid displacement in sands. Trans AIME 146:107-116

Carstens H (2009) Oil and gas available in Afghanistan. GeoExpro Mag 6(3). http://www.geoexpro.com/articles/2009/03/oil-andgas-available-in-afghanistan

Kingston J (1990) The undiscovered oil and gas of Afghanistan. Open-File Report 90-401, Department of the interior U.S. Geological Survey

Ministry of Mines and Petroleum of Afghanistan (2013) CNPCI report for Afghanistan Petroleum Authority

Nazari J, Nasiry F, Seddiqi N, Honma S (2015) Influence of relative permeability and viscosity ratio on oil displacement by water in petroleum reservoir. In: Proceedings of School of Engineering of Tokai University, vol 40, pp 15-20

Petzet A (2016) CNPC gets three Afghanistan Amu Darya blocks. Oil Gas J. http://www.ogj.com/articles/2012/01/cnpc-gets-threeafghanistan-amu-darya-blocks.html

Promotion of Oil and Gas Production Areas to the Private Sector Grant Agreement. No. H007-AF, Gustavson Associates report, Jul-2005. www.siteresources.worldbank.org/AFGHANISTAN EXTN/Resources/.../gustavasonreport.pdf

Seddiqi KN, Mahdi Z, Honma S (2016) Laboratory measurement of relative permeability of oil and water in sand. In: Proceedings of School of Engineering of Tokai University, vol 41, pp 47-51

\section{Publisher's Note}

Springelr Nature remains neutral with regard to jurisdictional claims in published maps and institutional affiliations. 